\title{
DE

\section{COMPETITIVENESS OF UKRAINE IN ASPECT OF THE EU INTEGRATION AND EASTERN PARTNERSHIP CONVERGENCE}

\section{KHARLAMOVA Ganna}

Taras Shevchenko National University of Kyiv, Ukraine

\begin{abstract}
:
Innovation is a concept that is more and more often used as a solution for increased competitiveness and economic development, either at organizational level or at a national one, but how is it created and what are the factors involved in the cycle education-innovationeconomic and social development? This article intents to clarify the above mentioned cycle and provide an insight on what innovation means and what are its components, especially from a macroeconomic point of view. The results show how important innovation and other components like education are for the national and global economic development.
\end{abstract}

Key words: EU, cointegration, smart policy, Eastern Partnership, Ukraine

\section{Introduction}

Today the EU is struggling from refugees' invasion as well as not full absorption of positive potential that migration flows can bring in. More and more the European states consider the expansion of the EU to the East as the potential threat (we see talks in the Netherlands about Ukrainian joining). Thus, the EU is testing its abilities through the Eastern Partnership (EaP). However the evidence is that the EaP bought not just positive trends (Kharlamova, 2015). There are a lot of researches devoted to a major concern for the EU's foreign policy towards the region of the Eastern partnership - socio-economic stability in link to migration and the level of economic stability (Barbone, Bonch-Osmolovskiy, Luecke, 2013; Raišienè, Bagdonienè, Bilan, 2014). But in the same time the involving the countries of the Eastern Partnership (EaP) stimulates the potential and competitiveness of the EaP states itself (Boonstra, Shapovalova, 2010). It is suggested (Korosteleva, 2012; Dickerson, Pore, 2015) that comprehensive policies and culture of competition play a crucial role in the investment climate and affect the costs, risks and barrier to competition faced by firms. Therefore, cornerstone of successful market economy lies in both creating an effective and comprehensive competition policy and the existence of a "culture of competition" in a country. Quite obvious is the fact of necessity of more 
researches on the EU's relations with key countries in the EaP that will provide sound insights into the major problems facing this region as well as into the key advances and remaining challenges in the political, economic and cultural relationships between the EU and these countries. It will thus not only contribute to a better understanding of the EU's partners, but also reveal major challenges to the European Union's neighbourhood strategy and policies. This will allow identifying of significant policy implications for the EU's approach to each of the countries individually and to the region on the whole. A relevant question for both the EaP and the EU policymakers is the potential for continued (and perhaps moderately increased) enlargement of the EU in the future.

\section{Investigation of economic convergence in the European Union}

Studies of the convergence presence between countries with different levels of economic development began in the 60s of XX century with the advent of the economic growth model of R. Solow. Among the conclusions of this model there were allegations of higher growth in countries that are further away from equilibrium (Krugman, 1995). That is, over time the gap between developed countries and developing countries must be reduced, according to this model.

There are different approaches to the definition of convergence and to the measurements of its speed. The most widely used are two concepts: $\beta$-convergence and $\sigma$-convergence.

The concept of $\beta$-convergence was proposed by $\mathrm{R}$. Barro and $\mathrm{H}$. Sala-i-Martin (1990). They found out that $\beta$-convergence is the inverse relationship between growth rates in the region and the initial level of development. Thus, poorer regions (or countries) have faster growth rates than richer one. Over time, the gap between regions with different levels of development is reducing, and an economic system, which is inherent to the phenomenon of convergence, in the long run tends to the equilibrium. In order to empirically check $\beta$-convergence it is necessary to estimate a regression model: dependence of the growth rate of the studied parameters (such as GDP per capita, the number of enterprises in the region per 1000 inhabitants, etc.) on its initial level, which in general can be represented by the following formula:

$$
\left(\frac{x_{z}}{y_{2}}\right)^{\frac{1}{t}}=a+b \cdot \ln y_{0}+\varepsilon \text {, }
$$

, where $\mathrm{y}_{0}, \mathrm{y}_{\mathrm{t}}$ - studied parameters mentioned in the initial and final time points, respectively; a,b - regression coefficients; $\varepsilon$ - random error.

The average rate of the studied index is $\left(\frac{y_{t}}{y_{0}}\right)^{\frac{1}{t}}$. significant one and has a negative sign, we can assert the existence of convergence. If $\mathrm{b}$ is positive, we can conclude the existence of divergence and the escape of the economic system from the equilibrium. This model is used to determine the presence of unconditional $\beta$-convergence. To study the conditional $\beta$-convergence it is 
necessary to extend the model with additional factor variables (not just the initial rate of development).

As for $\sigma$-convergence, it is defined as a reduction of future rate of variation (inequality, differentiation) in the levels of development of regions (countries). Not only rates of variations can be used, but as well the variance or standard deviation. However, the most informative indicator is the rate of variation, because it does not depend on the dimension and scale of variables. Variance and standard deviation are impractical to use in the presence of inflation (Young, Higgins, Levy, 2008). To confirm the presence of $\sigma$-convergence the equality is performed:

$\sigma_{t}<\sigma_{0}$, where $\sigma$ - the rate of variation; $t$ - duration of the period under consideration.

The coefficient of variation is calculated as follows

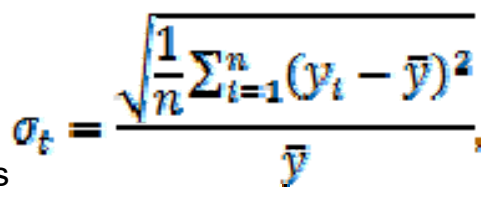

where $\bar{y}$ - the average of the studied parameter; $y_{i}$ - value of the studied index for the i-th object (region);

$\mathrm{n}$ - amount of objects (regions).

Hypotheses $\beta$ - and $\sigma$-convergence are interrelated but not equivalent. Absolute $\beta$-convergence indicates the existence of the tendency to reduce the size of GDP per capita, but random shocks affecting the economy of the countries (regions) could counteract this trend and temporarily increase the dispersion of the distribution of per capita GDP (Rapacki, Próchniak, 2009). The absolute $\beta$-convergence does not mean the existence of $\sigma$-convergence. The $\beta$-convergence is a necessary but not sufficient condition for the existence of $\sigma$-convergence.

Check the existence of convergence phenomenon for the inherent dynamics of the EU. The basis of the study will be GDP per capita, actually its dynamics over the past 10 years in 28 countries - the EU members. Table 1 shows the results of calculation of coefficients of variation, maximum level of GDP per capita (the EU), the minimum level of GDP per capita (the EU), the average level of GDP per capita (the EU) for the period from 2003 to 2013. Indicator of the gap between "richest" and "poorest" countries shows how many times the maximum per capita GDP is above the minimum.

Table 1: Statistics of GDP per capita for the EU Member States

\begin{tabular}{|l|l|l|l|l|l|l|l|l|l|l|l|}
\hline & $\mathbf{2 0 0 3}$ & $\mathbf{2 0 0 4}$ & $\mathbf{2 0 0 5}$ & $\mathbf{2 0 0 6}$ & $\mathbf{2 0 0 7}$ & $\mathbf{2 0 0 8}$ & $\mathbf{2 0 0 9}$ & $\mathbf{2 0 1 0}$ & $\mathbf{2 0 1 1}$ & $\mathbf{2 0 1 2}$ & $\mathbf{2 0 1 3}$ \\
\hline \hline $\begin{array}{l}\text { The coefficient } \\
\text { of variation }\end{array}$ & 0.4673 & 0.4649 & 0.4560 & 0.4658 & 0.4582 & 0.4279 & 0.4210 & 0.4402 & 0.4339 & 0.4226 & 0.4194 \\
\hline $\begin{array}{l}\text { The maximum } \\
\text { level of GDP } \\
\text { per capita (the } \\
\text { EU) }\end{array}$ & 60705 & 64929 & 68290 & 78383 & 84494 & 84393 & 79352 & 84764 & 88781 & 88318 & 90790 \\
\hline $\begin{array}{l}\text { The average } \\
\text { level of GDP }\end{array}$ & 22990 & 24320 & 25533 & 27942 & 29954 & 31249 & 30000 & 30717 & 31904 & 32369 & 33330 \\
\hline
\end{tabular}




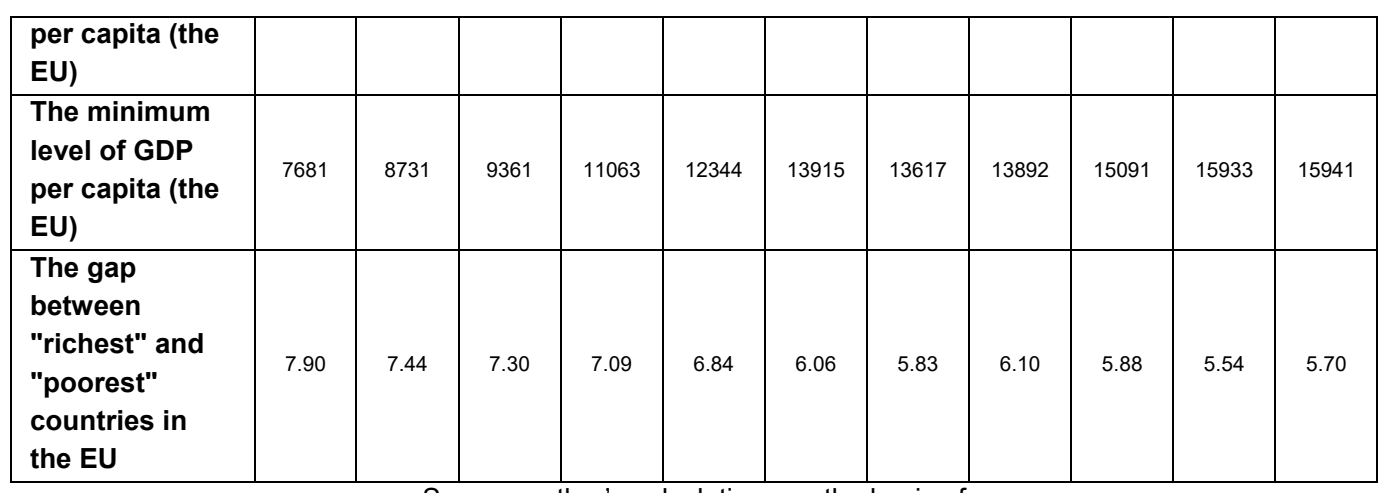

Source: author's calculations on the basis of

http://epp.eurostat.ec.europa.eu/portal/page/portal/eurostat/home/

Table 1 pictures that the value of the coefficient of variation decreased by more than 10 percent from 2003 to 2013. So we can assert the existence of $\sigma$ convergence for the EU. If in 2003 the highest GDP per capita among the EU member states exceeded the lowest in almost 8 times, then in 2013 the figure is higher only 6 times. So this economic system tends to the equilibrium. The average gap between the countries annually declines by $2.8 \%$. Thus it can be argued that in the absence of strong exogenous influences gap between EU countries by 2030 will be reduced by half. Note that in the EU the average GDP per capita increased in last 10 years by 1.5 times and is 33330 USD. For comparison the figure for Ukraine in 2013 is 7423 USD per person, 4.5 times lower than the European average.

According to some local experts (Coll, 2013) for a smooth entry into the EU it is desirable for Ukraine to increase the GDP by 300 billion USD. To overcome the significant gap in GDP per capita between the EU and Ukraine the annual GDP growth rate should be at least 6-7 per cent. Thus rough calculations suggest that for maintaining the trends of pre-war period the required annual increase in GDP in Ukraine will be reached only in 2020-2023 years (Yukhymenko, Misyac, 2013).

In this regard, the question appears: whether Ukraine is capable independently go to these indicators' level? Or perhaps it is possible only after but not before joining to the EU? Particularly with the proof of the existence of the convergence phenomenon it will be easier achieved the desired economic growth for new member state. May we consider the EaP as the mechanism to reach this convergence as well? And could any factors impact the convergence rate?

Before coming to the analyses of EaP explore the dynamics of the new EU member states in comparison with most developed countries, such as Germany and Luxembourg. Choose Poland, Lithuania, Latvia and Estonia, as they have much in common with Ukraine in their historical development. Besides all these 4 countries are new members of the European Union (2004) and belong to the so-called fifth wave of integration, while Germany and Luxembourg belong to the first wave (1957) (Kornivs'ka, Yaremenko, 2014). In order to eliminate the effects of inflation on the model, which distorts the real picture, we use the normalized value of GDP per capita, which is calculated by dividing this index in year $t$ to its value in the base year. 
Figure 1: Dynamics of normalized GDP value per capita for the EU

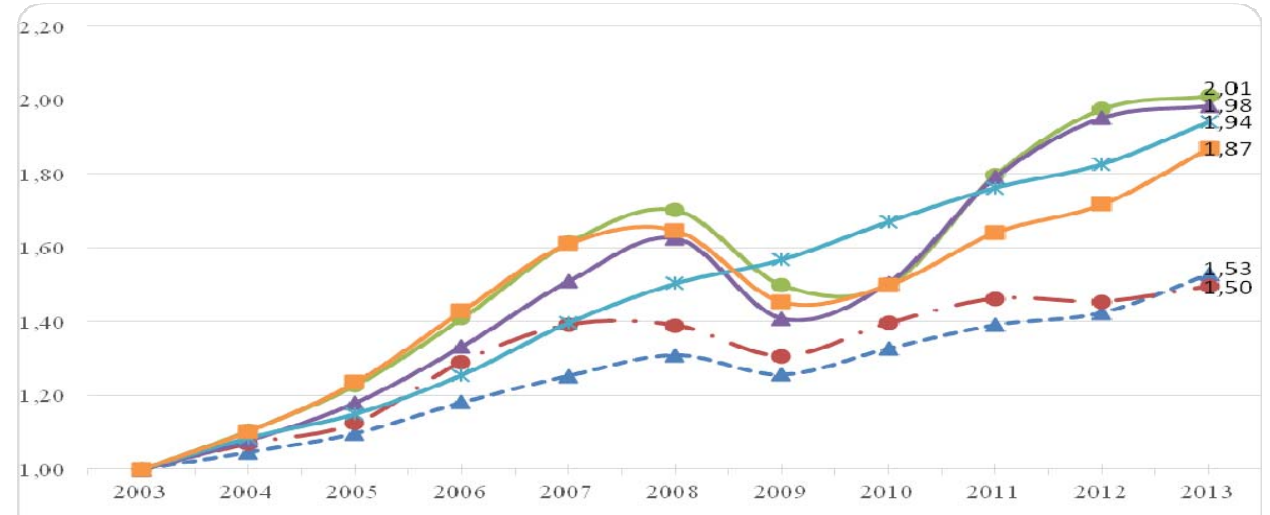

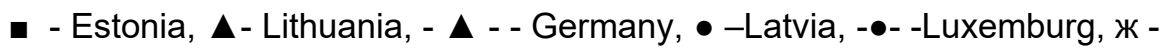
Poland

Source: Calculated by the author based on

http://epp.eurostat.ec.europa.eu/portal/page/portal/eurostat/home/

In Figure 1 countries with lower development index in the initial period grew at a faster pace. In particular, GDP per capita in Latvia and Lithuania in the past 10 years (the time of their membership in the EU) has increased by 2 times; in Poland and Estonia - 1.9 times. While in the countries - founders of the EU and most developed European countries, Germany and Luxembourg analyzed indicator increased only by 1.5 times for the same period. In addition, during the global financial crisis of 2008 2010 years Poland has developed in the most stable route. The graph shows that Poland is the only from 6 countries, which did not observed decline in GDP per capita in 2009. Consequently, states-applicants for membership in the European Union, especially Ukraine, should not afraid decrease in economy and deepening the gap between it and the more developed countries after accession to the association.

For the EaP states we see the following data: states itself have great levels of dispersion in analyzed indicator during the period, in times higher than the EU level (Table 2), in contrast to the EU, GDP per capita for the EaP much more varies over the period but has higher growth rates (Figure 2).

Table 1: Statistical indicators of GDP per capita growth (annual \%) for the EU and EaP States, 1961 - 2013

\begin{tabular}{|l|c|c|c|c|c|c|c|}
\hline & EU & Armenia & Moldova & Georgia & Belarus & Azerbaijan & Ukraine \\
\hline Mean & 2,3755319 & 3,9766724 & $-0,02443446$ & 1,8363566 & 3,5563317 & 3,92874157 & $-0,44490236$ \\
\hline StDev & 1,9667671 & 12,338646 & 9,64355119 & 10,853561 & 7,2960934 & 14,2330828 & 9,060356747 \\
\hline & & & & & & & \\
Dispersion & 3,8681727 & 152,24218 & 92,99807955 & 117,799787 & 53,232979 & 202,580647 & 82,09006437 \\
\hline
\end{tabular}


Studies in Business and Economics no. 11(3)/2016

\begin{tabular}{|c|c|c|c|c|c|c|c|}
\hline Min & $-4,695981$ & $-40,74694$ & $-30,6942341$ & $-45,325107$ & 11,596392 & $-24,2593992$ & $-22,5508475$ \\
\hline Max & 8,3077666 & 14,452855 & 10,60199081 & 15,2291572 & 12,217177 & 33,0304873 & 12,95365583 \\
\hline total & 53 & 23 & 33 & 48 & 23 & 23 & 26 \\
\hline
\end{tabular}

Source: author's calculations on the base of World Bank data http://data.worldbank.org/country

Figure 2: Dynamics of GDP per capita growth (annual \%) in the EU and the EaP states (1961-2014)

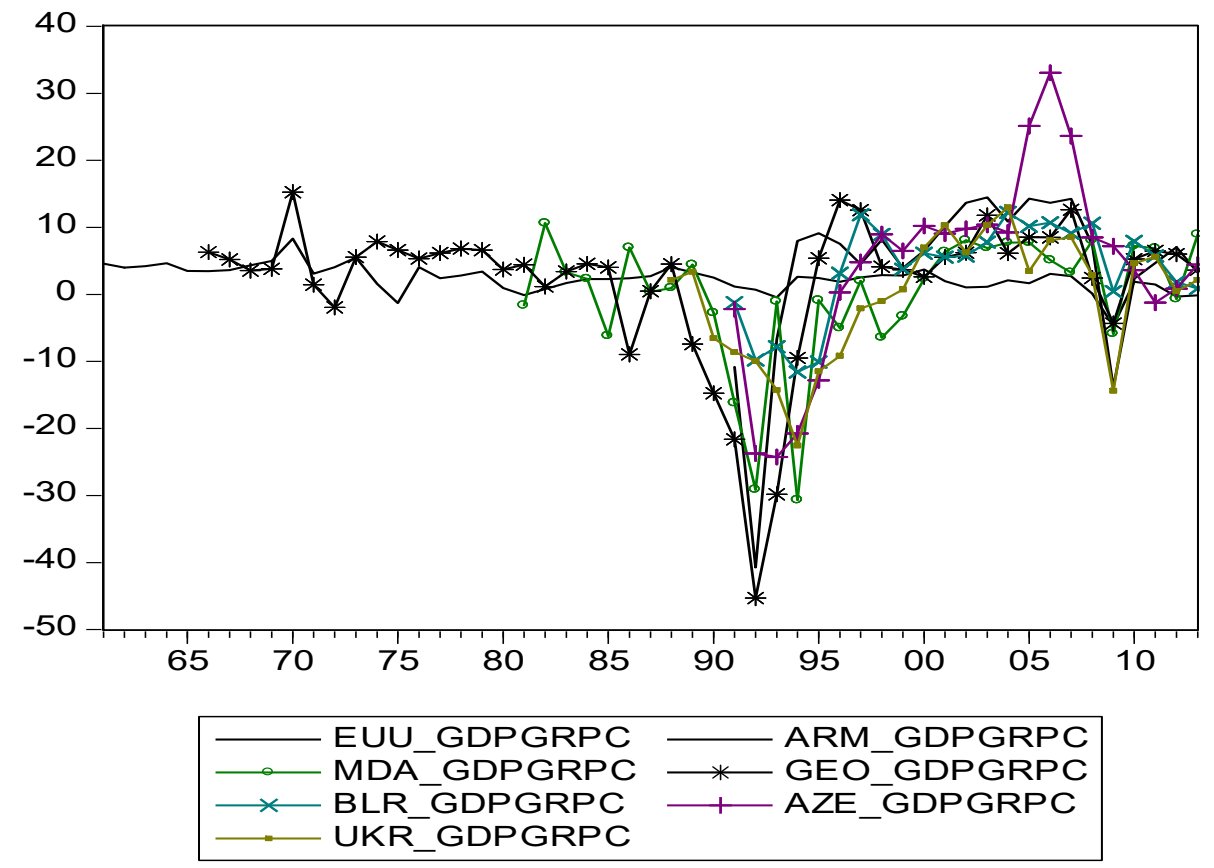

Source: author's calculations on the base of World Bank data http://data.worldbank.org/country

That is a signal of possibility for the EaP states to be involved in convergence process even in aspect of accession to the EU. Having a look on long period (Figure 3) we can conclude that over 1966-2013 there is no convergence, the gap between the "richest" and the "poorest" is varying, and increased dramatically in the crisis years. But as to period 2003-2013 we see (Table 3) the following:

1) the asymmetry shows how much data is distributed asymmetrically with respect to the normal distribution: having A > 0 in 2005-2007, 2009-2010 and 20122013 , then we conclude that much of the data has a value greater than the average over the EaP+EU; having A < 0 in 2003-2004, 2008 and 2011, then we conclude that a large part of the data has a value smaller than the average over the EaP\&EU. So, in crisis years GDP per capita in its growth in most EaP countries was quite small even in comparison to the average possible. However we have to note that the EaP was 
established just in 2009 to promote regional stability through trade agreements and democratic institution-building. And for the period 2009-2013 for the EaP states and the EU we see quite clear $\sigma$-convergence. That means the success of EaP project for the particular states that are involved in it. However, despite the detected $\sigma$ convergence the gap between the "richest" and the "poorest" is dramatically increasing. Having in mind that as "richest" is the EU level, we summarize the existence of increasing gap between the EaP states and the EU, thus, means that for the EaP states joining to the EU umbrella means quite fast level of increasing and coming to some unified level closer to the EU tendencies, but does not guarantee the improvement of economic position up to the EU level.

Figure 3: Statistics of GDP per capita growth (annual \%) for the EU and EaP States, over 1961 - 2013

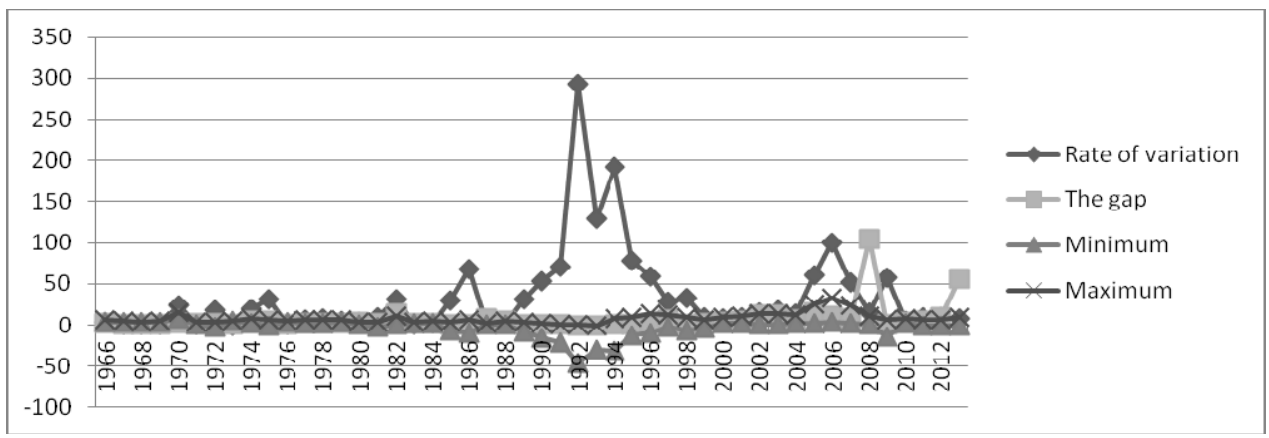

Source: author's calculations on the base of World Bank data http://data.worldbank.org/country

Table 3: Statistical indicators of GDP per capita growth (annual \%) for the EU and EaP States, over 2003-2013

\begin{tabular}{|c|c|c|c|c|c|c|c|c|c|c|c|}
\hline & 2003 & 2004 & 2005 & 2006 & 2007 & 2008 & 2009 & 2010 & 2011 & 2012 & 2013 \\
\hline Mean & 8,95 & 8,74 & 10,13 & 11,71 & 10,58 & 5,68 & $-5,09$ & 4,70 & 4,22 & 2,16 & 3,29 \\
\hline St.dev. & 4,27 & 3,80 & 7,81 & 10,02 & 7,19 & 3,86 & 7,60 & 2,30 & 2,99 & 3,09 & 2,95 \\
\hline Rate of variation & 18,20 & 14,43 & 61,06 & 100,41 & 51,75 & 14,93 & 57,69 & 5,28 & 8,93 & 9,58 & 8,70 \\
\hline Asymmetry & $-0,90$ & $-0,78$ & 1,23 & 2,01 & 0,87 & $-0,30$ & 0,28 & 0,26 & 1,29 & 0,99 & 1,11 \\
\hline Minimum & 1,10 & 2,10 & 1,65 & 3,03 & 2,69 & 0,10 & 14,42 & 1,88 & 1,23 & $-0,69$ & $-0,16$ \\
\hline Maximum & 14,45 & 12,95 & 25,11 & 33,03 & 23,64 & 10,57 & 7,16 & 7,93 & 6,86 & 7,02 & 8,91 \\
\hline The gap & 13,11 & 6,16 & 15,19 & 10,89 & 8,78 & 104,85 & 0,50 & 4,22 & 5,58 & 10,23 & 56,67 \\
\hline
\end{tabular}

Source: author's calculations on the base of World Bank data http://data.worldbank.org/country 


\section{Smart policy for Ukraine and the EaP states for more efficient integration and convergence}

As the decision we propose smart policy that should be set out to achieve the following major objectives as shown in the following table:

\begin{tabular}{|c|c|c|}
\hline Objective & Aim & What do we want to achieve \\
\hline 1 & $\begin{array}{l}\text { Define \& set parameters for } \\
\text { macroeconomic development in the } \\
\text { target economies that are linked } \\
\text { directly and indirectly to economic } \\
\text { effects: convergence and } \\
\text { cointegration assessments }\end{array}$ & $\begin{array}{l}\text { Assessing economic policies and competitive } \\
\text { culture in the target economies related to aggregate. } \\
\text { Such analysis helps to trace Evolution and Policy } \\
\text { Options for Better Outcomes in aspect of main } \\
\text { macroeconomic characteristics: GDP growth per } \\
\text { capita; wages level; contribution to poverty level; } \\
\text { contribution to financial Markets; fiscal policy; level } \\
\text { of corruption; social development; brain/drain; } \\
\text { banking system development; economic reforms } \\
\text { development; SME operating; competitiveness and } \\
\text { competition culture development. }\end{array}$ \\
\hline 2 & $\begin{array}{l}\text { Develop macroeconomic tools for } \\
\text { policies of EaP and the EU to } \\
\text { neutralize major problems facing } \\
\text { this region as well as into the key } \\
\text { advances and remaining challenges } \\
\text { in the political, economic and } \\
\text { cultural relationships between the } \\
\text { EU and the EaP countries }\end{array}$ & $\begin{array}{l}\text { Developed mechanisms suppose to minimize or } \\
\text { erase potential sources of tensions in the EaP } \\
\text { functioning and its convergence with the EU mostly } \\
\text { in aspects of migration and economic integration } \\
\text { and convergence: } \\
\text { - EU member states' uneven engagement in the } \\
\text { policy process: while Western European member } \\
\text { states' participation in the multilateral track is weak, } \\
\text { their involvement is needed to turn the Eastern } \\
\text { Partnership into a EU-wide foreign policy (Boonstra, } \\
\text { Shapovalova, 2010); } \\
\text { - Partner countries' different level of involvement in } \\
\text { the multilateral track, which is perceived by some of } \\
\text { them as a 'one-size-fits-all'exercise; } \\
\text { - The combination, in the multilateral track, of a logic } \\
\text { based upon joint ownership, inclusiveness and } \\
\text { socialization with some elements reflecting a more } \\
\text { hierarchical approach and limiting participation. }\end{array}$ \\
\hline 3 & $\begin{array}{l}\text { Too boost competitiveness level } \\
\text { through competition policy and } \\
\text { competition culture }\end{array}$ & $\begin{array}{l}\text { Competition policy is an essential element of good } \\
\text { governance. It is important to promote competition } \\
\text { culture in the EU and EaP as better understanding } \\
\text { of the advantages of competition that further } \\
\text { contributes to better functioning of markets. In times } \\
\text { of economic slowdown, it is particularly important } \\
\text { that policy makers especially in Eastern Partnership } \\
\text { countries understand the beneficial effects of } \\
\text { competition on growth and the harm that could } \\
\text { result from a relaxation of the competition rules. } \\
\text { Thus it would be directed towards the adaptation of } \\
\text { economies and societies of the Eastern Partnership } \\
\text { countries to the European standards. }\end{array}$ \\
\hline
\end{tabular}

Today Ukraine is a country with a moderate level of competitiveness. In order to get into the group of more competitive countries, it is necessary significantly 
increase exports and attract much more foreign investments. To achieve this goal, the state should implement a series of measures to improve the investment climate and the development of priority economic sectors or industries that are underdeveloped but have considerable potential. A lot of surveys (Kharlamova, Vertelieva, 2013; Lukyanenko, Oliskevych, 2014) showed that Ukraine has the potential for further development. In particular, its competitive advantages are: significant presence and a wide variety of natural resources; good climatic conditions that favor the development of agriculture; high levels of education and literacy; developed network of academic and research institutions; the openness of the economy of Ukraine and its integration into global processes.

One of the important factors that may contribute to the further development of Ukraine is the remained research sector in the state. Unfortunately, currently scientifictechnical and innovation factor does not act as a source of economic growth. The main reason is the low level of demand from the domestic economy to the forefront of technology and scientific development. Proposed research results are not used in the economy: science and technology continued loss the staff and reduce logistical means. Total expenditures on research and development as a share of GDP (research intensity of GDP) for 2000-2014 in Ukraine decreased from $1.2 \%$ to $0.7 \%$. For comparison, the EU measures of the knowledge intensity of GDP on average $2 \%$, in Finland and Sweden - 4\%, and Germany - 3\%. Smart specification is becoming most sufficient discussion in the EU to fast convergence of new members.

Another area of reform should be in the energy sector. Ukrainian economy is one of the most energy consumed in the world: we spend 3-5 times more energy per unit of GDP than in Eastern Europe. This increases the burden on the state budget due to the need to subsidize the purchase of excess energy, the increase in emissions. This creates problems for economic competitiveness in the future.

Other way to increase the competitiveness of Ukraine is the development of transport infrastructure. Today the transit potential of the country is not used. As a result, there are no new jobs, and the state budget does not receive additional revenue. In 2012, there were significant improvements in logistics activities. According to the World Bank in 2012 Ukraine has risen from 102th to 66th place in the Logistics Performance Index [http://data.worldbank.org/data-catalog/logistics-performanceindex]. These changes are the result of football championship "Euro 2012" that was hold in Ukraine. But, despite the significant development of transport infrastructure, transit highways were not built. Construction of new highways can be a significant impetus to the development of the transport sector.

An important sector of Ukrainian economy is agriculture. Ukraine has great natural resources and agricultural potential, but uses it not very effectively. The main problems of agriculture are: low competitiveness in foreign markets and its noncompliance with international standards of quality and safety; low economic efficiency of agriculture compared to other countries, the use of outdated technologies; dominance in the export of raw materials with low processing; reduction in soil fertility and erosion due to the growth of their irrational use. The main objective of reforms in 
agriculture should be its technical upgrading and transformation into an efficient, competitive domestic and international markets sector. To achieve these goals it is necessary to create conditions for the inflow of investments that will improve the efficiency of agricultural production. In particular, it should address the following objectives: improvement of land relations; improving the mechanisms of state support for agricultural producers; improving the efficiency of public administration.

One more important area of quick reforms is the sphere of legal support of business activities. The big drawback is the complexity of procedures for registration, obtaining the necessary permits and so on. The level of bureaucracy in Ukraine is much higher compared to other European countries. Simplifying these procedures could have a significant impact on the ease of doing business in the country thus quick adaptation to the EU standards.

The above measures have a great potential to contribute to the development of priority sectors, and hence the growth of exports and increasing investment attractiveness of Ukraine, which are crucial factors of its competitiveness.

\section{Conclusion and Discussion}

The competitiveness of Ukraine is characterized by the presence of mechanisms and means of creating conditions that contribute to solving problems of national security, economic development and improvement of people's lives. The components of competitive advantage of the economy could be absorbed from the neighbor effects.

„In 2014-2015, Ukraine took the 76th place among 144 countries in terms of international competitiveness, rising up 8 positions compared to last year. Two years ago, Ukraine ranked $73 \mathrm{~d}$ place. Over the past year, progress has been made due to a more positive perception of institutions and market efficiency and better results in education. The main problems still are the restructuring of the institutional structure. The analyses of Ukraine's position according to the known ratings such as the Human Development Index, a Global Peace Index, Corruption Perceptions Index, Index of Globalization, Index of Ease in Doing Business, Index of Media Freedom, Economic Freedom Index had detected the positive changes in recent years only in increasing the ease of doing business associated with changes in legislation. Ukraine's competitive advantages include high levels of education and literacy, integration into global processes. However over the past few years Ukraine's position experienced deterioration in terms of economic freedom, peace and freedom of the media.

Analysis of studies of foreign and domestic scientists and surveys of international rating agencies highlighted the factors which most determine the competitiveness of any country as well as Ukraine, such as: GDP per capita, FDI inflows into the economy, foreign trade balance, exports. All these factors supposed to be improved after integration of Ukraine to the EU, as the Ukrainian politics say.

To assess the possible effects of European integration we conducted some calculations to determine whether the inherent dynamics of the EU has a convergence 
phenomenon itself and how it could be positivle used by Ukraine and other states of the EaP. The basis for constructing a model of economic convergence is GDP per capita growth rate over the past 10 years in 28 countries - EU members and then in the data group the EaP+EU. The study found that the value of the coefficient of variation from 2003 to 2013 decreased by more than 10 percent, indicating the presence of $\sigma$ convergence. Thus, if in 2003 the highest GDP per capita among the EU member states exceeded the lowest in almost 8 times, as in 2013 the figure was higher only 6 times. The average gap between the EU countries annually declined by $2.8 \%$, indicating the movement of the economic system to the equilibrium. If save this dynamics and the absence of strong exogenous influences it could be argued that the gap between the EU countries by 2030 will be reduced by half.

Quite similar results received in the data for the EaP (plus the EU): approaching to the EU provided states with convergence effects; however their gap from the EU level is actually increasing.

Meanwhile the examining of the dynamics of the countries - new EU members such as Poland, Lithuania, Latvia and Estonia, which in its historical development have much in common with Ukraine, in comparison with most developed countries, such as Germany and Luxembourg, it was found that countries with lower initial index grew at a faster pace in analyzed period. In particular, GDP per capita in Latvia and Lithuania in the past 10 years (after joining the EU) has increased by 2 times in Poland and Estonia - 1.9 times. While for the founders of the EU, such as Germany and Luxembourg, the anayzed index for the same period increased only by 1.5 times.

Thus, to implement the smart policy in order to maintain sustainable development, Ukraine should take a number of measures to improve the competitiveness based on minimizing the negative external impacts and maximizing the use of the country's competitive advantages, such as: availability of large and very diverse natural resources; good climatic conditions that favor the development of agriculture; high levels of education and literacy; the openness of the economy of Ukraine and its integration into global processes.

The results of this study can be used to improve existing methods of convergence evaluation for assessing competitiveness and existing practical recommendations to improve Ukraine's position in the world. Results from the study can be used in the formation of economic policy and development plans for Ukraine's strategy to join the EU.

Further researches of competitiveness are in great importance because of its global development dynamics and speed of changes. Another important issue that is not explored, it is to build a model of the key factors in the competitiveness that would be universal for most countries

\section{References}

Barbone, L., Bonch-Osmolovskiy, M., Luecke, M. (2013) Labour Migration from the Eastern Partnership Countries: Evolution and Policy Options for Better Outcomes, EuropeAid/130215/C/SER/Multi 
Barro, R. J., Sala-i-Martin, X. (1990) Economic Growth and Convergence across the United States, Working Paper 3419, NBER, 69 p.

Boonstra, J., Shapovalova, N. (2010). The EU's Eastern Partnership: One year backwards, Working papers, FRIDE, May 2010, Available at: www.fride.org

Coll, E. (2013).The classification of EU and Eastern Partnership countries regarding economic development level - a dynamic approach. Research Papers of Wrocław University of Economics, No.286, p. 144-156

Dickerson, D.; Pore, W. (2015) A Reconcilable Strategy for Sustaining Vietnam's Competitive Advantage, VNU Journal of Science: Economics and Business, 31 (2), pp.51-62 Available at http://tapchi.ueb.edu.vn/

Kharlamova, G. (2015) The European union and the Eastern Partnership: convergence of economies, Procedia Economics and Finance, 27, pp. 29-41 doi:10.1016/S2212$\underline{5671(15) 00968-5}$

Kharlamova, G., Vertelieva, O. (2013) The International Competitiveness of Countries: Economic-mathematical Approach, Economics \& Sociology, 6(2), p. 39-52. DOI: 10.14254/2071-789X.2013/6-2/4

Kornivs'ka, V. O., Yaremenko, V. H. (2014). Intehracijni perspektyvy Ukrayiny v konteksti instytucijnoyi efektyvnosti $v$ krayinax Yevropejs"koho Soyuzu ta Mytnoho Soyuzu, Zovnishnya torhivlya: ekonomika, finansy, pravo, (2), p. 5-11.

Korosteleva, E. (2012). Eastern Partnership: A New Opportunity for the Neighbours?, London, Routledge, 200 pp. Available at: https://kar.kent.ac.uk/id/eprint/39147

Krugman, P. (1995) Growing World Trade: Causes and consequences, Brookings Papers on Economic Activity, p. $327-377$.

Lukyanenko, I.; Oliskevych, M. (2014) Labour Market in Ukraine: an Empirical Dynamic Analysis Using Error Correction Model, Bulletin of Taras Shevchenko National University of Kyiv. Economics, 6(159), p. 52-58

Raišienè, A. G., Bagdonienè, J., \& Bilan, Y. (2014). Inter-Institutional Interaction Results: The Effect of EU Programs on the Reduction of Long-Term Unemployment. Procedia Economics and Finance, 16, p. 641-650.

Rapacki, R., Próchniak, M. (2009). Real beta and sigma convergence in 27 transition countries, 1990-2005. Post-Communist Economies, 21(3), p. 307-326

Young, A. T., Higgins, M. J., Levy, D. (2008). Sigma convergence versus beta convergence: Evidence from US county-level data. Journal of Money, Credit and Banking, 40(5), p. 1083-1093.

Yukhymenko, V., Misyac, T. (2013). Intehracijni priorytety Ukrayiny v konteksti svitovyx transformacijnyx procesiv. Visnyk Kyyivs"koho nacional"noho torhovel"noekonomichnoho universytetu, (2), p. 5-17.

On-line sources:

http://eeas.europa.eu/eastern/index_en.htm

Eurostat statistics. Available at:

http://appsso.eurostat.ec.europa.eu/nui/submitViewTableAction.do

http://en.wikipedia.org/wiki/European_Neighbourhood_Policy

http://en.wikipedia.org/wiki/Eastern_Partnership

http://www.enpi-info.eu/mainmed.php?id=686\&id type=9\&lang id=450

http://www.cfr.org/europe/european-unions-eastern-partnership/p32577 